\title{
SISTEM INFORMASI GEOFISIKA DI STASIUN GEOFISIKA KELAS III TENATE BERBASIS WEB
}

\author{
Rusdin Womboo ${ }^{1}$, Moh.Jamil ${ }^{2}$, Rosihan $^{3}$ \\ Program Studi Teknik Informatika, Fakultas Teknik, Universitas Khairun \\ Jl.Jati Metro, Kota Ternate Selatan \\ E-mail : rusdinwomboo@gmail.com ${ }^{1}$,jamilkhairun@gmail.com ${ }^{2}$, icanunkhair@gmail.com ${ }^{3}$
}

(Naskah masuk: 20 April 2019, diterima untuk diterbitkan: 20 Oktober 2019)

\begin{abstract}
Abstrak
BMKG atau sering disebut dengan Badan Meteorologi, Klimatologi dan Geofisikan, Merupakan sebuah instansi yang menangani tentang masalah gempabumi dan tsunami,penyebaran petir, dan tanda waktu (Hilal) dan lainlain yang dapat digunakan untuk tujuan penelitian. Adapun tujuan yang akan dicapai adalah membuat sistem informasi geofisika di stasiun geofisika kelas III ternate berbasis web. Metode penelitian yang digunakan dalam skripsi ini adalah metode waterfall yang meliputi komunikasi perencanaan, pemodelan, konstruksi, dan deployment. Dengan menggunakan Microsoft visio untuk pemodelan aplikasi. Sedangkan bahasa pemrograman yang dipakai adalah PHP dengan menggunakan database MySQL. Hasil yang dicapai berupa suatu aplikasi untuk website yang dapat memperoleh informasi tentang geofiisika. Misalnya informasi-informasi gempa bumi dan tsunami yang terbaru dari BMKG. Kesimpulan yang didapat dari penelitian ini adalah sebuah sistem informasi geofisika berbasis web yang bisa digunakan masyarakat untuk mendapatkan informasi dari BMKG. Pengujian yang dilakukan deengan menggunakan metode blackbox dan hasil pengujian menunjukan bahwa aplikasi sudah sesuai dengan perancangan.
\end{abstract}

Kata Kunci: (BMKG) Sistem Informasi Geofisika di Stasiun Geofisika Kelas III Ternate Website, PHP, MySQL

\section{GEOPHYSICAL INFORMATION SYSTEM IN GEOPHYSICAL STATION CLASS III OF TERNATE BASED ON WEBSITE}

\begin{abstract}
Abstrack
BMKG or often referred to as the Meteorology, Climatology and Geophysics Agency, It is an agency that handles earthquake and tsunami problems, lightning spreads, and timestamps (Hilal) and others that can be used for research purposes. The goal to be achieved is to make a geophysical information system at the webbased class III ternate geophysical station. The research method used in this thesis is the waterfall method which includes communication planning, modeling, construction, and deployment. By using Microsoft Visio for application modeling. While the programming language used is PHP by using a MySQL database. The results achieved in the form of an application for websites that can obtain information about geofiiska. For example the latest earthquake and tsunami information from BMKG. The conclusion obtained from the writing of this thesis is an application of a web-based geophysical information system that can be used by the community to find information from BMKG. Tests carried out using the Black Box method. The results of the applications that have been tested have gone very well.
\end{abstract}

Keywords: (BMKG) Geophysical Information System at Geophysics Station Class III Ternate Website, PHP, $M y S Q L$

\section{PENDAHULUAN}

1.1. Latar Belakang

Pada era globalisasi seperti sekarang ini, kebutuhan akan informasi yang tepat dan akurat sangatlah diperlukan, baik bagi instansi pemerintahan maupun swasta. Komputer sesuai dengan fungsinya sebagai salah satu alat yang berguna untuk mengolah data menjadi sebuah informasi yang tepat, akurat dan memiliki peranan yang cukup penting dalam penyediaan informasi yang diperlukan.
Stasiun Geofisika Kelas III Ternate merupakan salah satu Unit Pelaksana Teknis (UPT) Badan Meteorologi Klimatologi dan Geofisika (BMKG). Stasiun Geofisika Kelas III Ternate mempunyai tugas pokok yaitu berupa kegiata pengamatan, pengolahan dan penyebaran data geofisika di wilayah Maluku Utara. Data yang diamati dan diolah meliputi data gempa bumi dan tsunami, data petir dan data tanda waktu (Hilal). Dalam penyebaran informasi BMKG terutama di Stasiun Geofisika Kelas III Ternate harus cepat dan akurat karena sesuai visi dan misi BMKG. 
Dalam proses pengolahan dan penyebaran data Stasiun Geofisika Kelas III Ternate belum terintegrasi dengan baik sehingga proses penyebaran informasi gempa bumi dan tsunami, petir dan tanda waktu tidak sampai ke masyarakat.

Setelah meninjau peranan internet dalam penyedian informasi bagi berbagai pihak yang memerlukannya, maka penulis mempunyai keinginan untuk membuat sistem informasi berbasis web. Penulis akan membangun sistem berbasis web di Stasiun Geofisika Kelas III Ternate. Penulis akan membangun sistem berbasis web ini didasarkan atas keinginan penulis untuk menyediakan informasi diseputar Stasiun Geofisika Kelas III Ternate pada masyarakat umum. Dengan demikian penulis akan mengangkat masalah ini dalam tulisan sebagai skripsi yang berjudul "Sistem Informasi Geofisika Di Stasiun Geofisika Kelas Iii Ternate Berbasis Web".

\subsection{Rumusan Masalah}

Berdasarkan latar belakang diatas, maka rumusan masalah dari penelitian ini adalah bagaimana membangun suatu sistem informasi di Stasiun Geofisika Kelas III Ternate Berbais Web.

\subsection{Batasan Masalah}

Berdasarkan perumusan masalah diatas, maka penulis membatasi masalah dalam penelitian sebagai berikut:

1. Membangun sistem informasi di Stasiun Geofisika Kelas III Ternate Berbasis web.

2. Data yang diolah adalah data geofisika yang meliputi data gempa bumi dan tsunami, data penyebaran petir, dan tanda waktu (hilal).

\section{LANDASAN TEORI}

\subsection{Penelitian Terkait}

Judul yang diajukan pada tugas akhir yaitu "Sistem Infornasi Geofisika di Stasiun Geofisika Kelas III Berbasis Web" didalamnya membahas tentang informasi gempa bumi dan tsunami, listrik udara, dan tanda waktu sehingga dalam proses pengolaan dan penyebaran data Stasiun Geofisika Kelas III Ternate bisa sampai ke masyarakat dengan cepat dan akurat. Adapun beberapa studi sejenis yang menjadi referensi pada penulisan tugas akhir ini adalah sebagai berikut:

Rancang Bangun Sistem Informasi Metorologi Klimatologi dan Geofisika Di Stasiun BMKG Kelas I Bandung Berbasis Web (Studi Kasus BMKG Bandung). Sistem ini dirancang menggunakan bahasa pemrograman PHP dan MySQL adalah databasenya. Adapun tujuan aplikasi ini adalah untuk mempermudah proses kegiatan yang dikerjakan dapat dilakukan secara mudah dan cepat [5].

\subsection{Konsep Dasar Sistem}

Secara umum dapat dikatakan bahwa sistem adalah suatu kelompok dari bagian-bagian tertentu yang saling berhubungan guna mencapai suatu tujuan
tertentu.Suatu sistem dapat didefinisikan sebagai suatu kesatuan yang terdiri dari dua atau lebih komponen atau subsistem yang berinteraksi untuk mencapai suatu tujuan.

\subsection{Sejarah Singkat Stasiun Geofisika Kelas III Ternate}

Stasiun Geofisika Kelas III Ternate berdiri sejak tahun 1986, yang beralamat di Jln. Bali Bunga Kel. Tabona, Kec.Ternate Selatan. Stasiun Geofisika Kelas III Ternate melaksanakan kegiatan operasionalnya meliputi kegiatan pengamatan, pengolahan dan penyebaran data-data geofisika. Data-data yang diamati dan diolah yaitu data gempabumi dan tsunami, data petir, dan data hilal [2].

\subsection{Prinsip Dasar Metode Geofisika}

Geofisika adalah ilmu yang mempelajari penerpan konsep dan hukum fisika pada masalah atau fenomena kebumian, dalam geofisika dikenal beberpa metode explorasi geofisika, yaitu teknik-teknik yang didasarkan pada konsep dan hukum fisika untuk memperkirakan distribusi parameter atau sifat bawahpermukaan (subsurface), distribusi parameter fisika seperti rapat massa $\sigma$ ), suseptibilitas magnektik $(\mathrm{k})$, magnetik (k) kecepatan rambat gelombang seismik (vp,vs) resistivitas $(\rho)$ atau konduktivitas $(\sigma=\rho \square-1)$ dan sebagainya berasosiasi dengan kondisi dan struktur geologi tertentu. Dengan demikan penyelidikan menggunakan metode geofisika dapat dimanfaatkan untuk keperluan studi geologi, eksplorasi sumber daya alam (air, tanah,mineral, geotemal, minyak dan gas bumi) serta studi lingkungan.

Beberapa contoh kajian dari geofisika bumi padat misalnya seismologi yang mempelajari gempa bumi, ilmu tentang gunung api (gunung berapi) atau Volcanologi, geodinamika yang mempelajari dinamika pergerakan lempeng-lempeng dibumi, dan eksplorasi seismik yang digunakan dalam pencarian hidrokarbon [2].

\subsection{Gempa Bumi dan Tsunami}

Gempa bumi adalah getaran asli dari dalam bumi, bersumber di dalam bumi yang kemudian merambat ke permukaan bumi akibat rekahan bumi pecah dan bergeser dengan keras. Penyebab gempa bumi dapat berupa dinamika bumi (tektonik), aktivitas gunungapi, akibat meteor jatuh, longsoran (di bawah muka air laut), ledakan bom nuklir di bawah permukaan. Gempa bumi tektonik merupakan gempa bumi yang paling umum terjadi merupakan getaran yang dihasilkan dari peristiwa pematahan batuan akibat benturan dua lempeng secara perlahan-lahan itu yang akumulasi energi benturan tersebut melampaui kekuatan batuan, maka batuan di bawah permukaan. Proses gempa tektonik secara diagramatis terlihat pada gambar 1 [1]. 


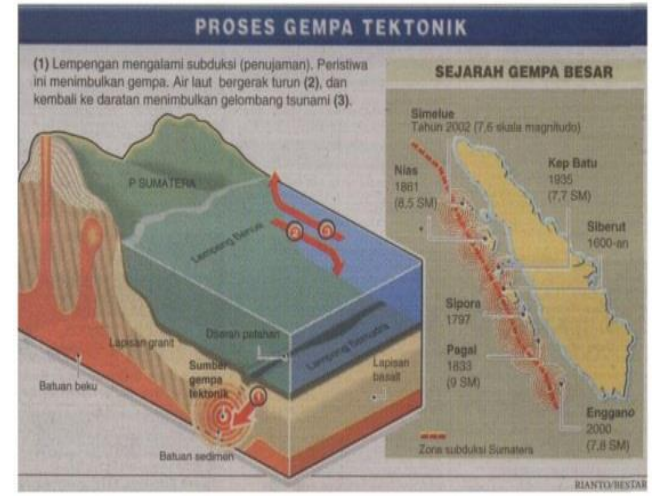

Gambar 1 Proses Gempa Tektonik [7]

\subsection{Lightning Detector (Detektor Petir)}

Prinsip kerja peralatan Lightning Detector yaitu saat terjadi petir, maka petir akan mengeluarkan gelombang elektromagnetik. Gelombang elektromagnetik inilah yang kemudian ditangkap oleh sensor LD berdasarkan frekuensinya, yang kemudian diterjemahkan oleh PCI Card Strom Tracker. Dengan Program Display LD/2000, maka hasilnya dapat terlihat berbagai macam parameter petir (Buletin, 2015). Dapat dilihat pada gambar 2.

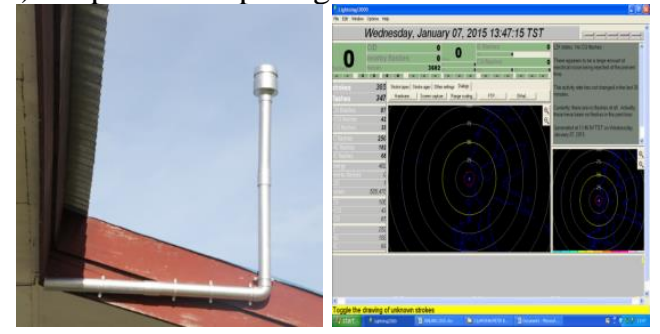

Gambar 2. Alat Lightning Detector

(Stageof Tnt, 2017)

\subsection{Tanda Waktu (Rukyat Hilal)}

Keteraturan peredaran Bulan dalam mengelilingi Bumi, dan Bumi dengan Bulan dalam mengelilingi Matahari memungkinkan manusia untuk mengetahui penentuan waktu. Salah satu penentuan waktu adalah penentuan awal bulan Hijriah yang didasarkan pada peredaran Bulan mengelilingi Bumi. Penentuan awal bulan Hijriah ini sangat penting bagi umat Islam dalam penentuan awal tahun baru Hijriah, awal bulan Ramadlan, hari raya Idul Fitri dan hari raya Idul Adha (Laporan Hilal, 2017).

Badan Meteorologi, Klimatologi, dan Geofisika (BMKG) sebagai institusi pemerintah salah satu tupoksinya adalah memberikan pelayanan data tanda waktu dalam penentuan awal bulan Hijriah. Gambar 2.4 merupakan alat teropong vixen dan informasi yang disampaikan meliputi:

1. Waktu Konjungsi (Ijtima') dan Waktu Terbenam Matahari

2. Data Hilal saat Matahari terbenam untuk Beberapa Kota di Indonesia

3. Peta Ketinggian Hilal

4. Peta Umur Bulan

5. Peta Lag

6. Peta Fraksi Illuminasi
7. Objek Astronomis Lainnya yang Berpotensi Mengacaukan Rukyat Hilal

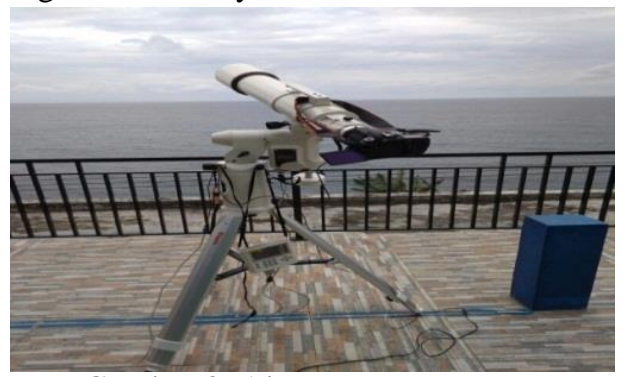

Gambar 3 Alat Teropong Vixen

(Stageof Tnt, 2017)

2.8 Metode Pengembangan Perangkat Lunak

Metode waterfall merupakan model pengembang an sistem informasi yang sistematik dan sekuensial. Dapat dilihat pada gambar 4 metode waterfall.

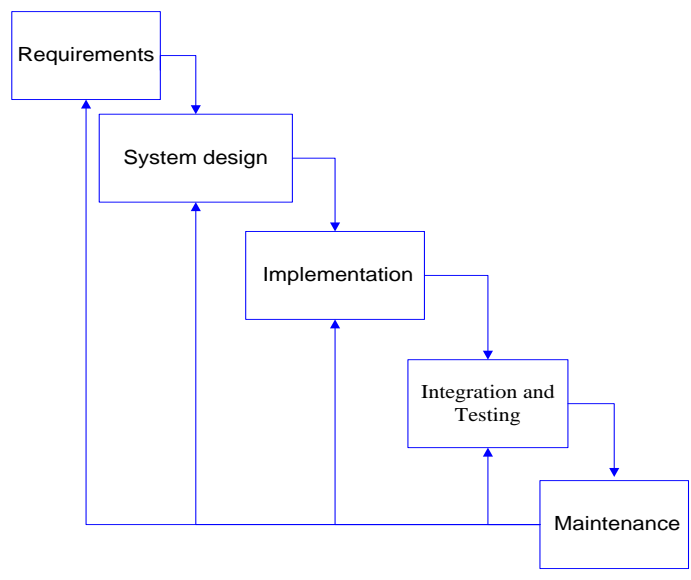

Gambar 4 Metode Waterfall [1]

\subsection{PHP (Hypertext Preprocessor)}

PHP (PHP Hypertext Preprocessor) dikenal sebagai suatu bahasa scripting yang menyatu dengan tag-tag HTML, dieksekusi di server dan digunakan untuk membuat web yang dinamis. Interpreter PHP dalam mengeksekusi kode PHP pada sisi server disebutserver side. Artinya, semua sintaks yang diberikan akan sepenuhnya dijalankan pada server sedangkan yang dikirimkan ke browser hanya hasilnya saja.Seluruh aplikasi berbasis web dapat dibuat dengan PHP.

\section{METODOLOGI PENELITIAN}

\subsection{Metode Pengumpulan Data}

Pengumpulan data-data geofiska seperti data gempabumi dan tsunami, data penyebaran petir dan data hilal dengan cara melakukan tinjauan langsung di kantor Stasiun Geofisika Kelas III Ternate (BMKG) dilakukan dengan cara:

1. Studi Pustaka

Studi pustaka dilakukan dengan mencari bukubuku dan jurnal yang menunjang materi tentang gempa bumi dan tsunami, tanda waktu, dan petir.

2. Pengamatan (Observasi )

Merupakan pengumpulan data secara langsung terhadap objek permasalahan yang akan dibahas. 
Observasi yaitu dengan datang langsung ke lokasi penelitian untuk memperoleh data yang dibutuhkan yakni dikantor Stasiun Geofisika Kelas III Ternate beralamat di jalan bali bunga kel. Tabona kecematan ternate selatan propinsi maluku utara.

3. Wawancara

Pengumpulan data dilakukan dengan cara mewawancarai langsung pihak-pihak yang terkait, dalam hal ini Kepala Stasiun Geofisika Kelas III Ternate, serta sumber-sumber lainnya guna mendapatkan gambaran permaslaahan yang sebenarnya.

3.2 Langkah-Langkah Penelitian

Langkah-langkah yang dilakukan untuk pengembangan sistem dalam penelitian ini menggunakan metode waterfall yang dibagi dalam beberapa langkah. Seperti pada Gambar 4 menunjukan urutan dan langkah-langkah dalam metode waterfall.

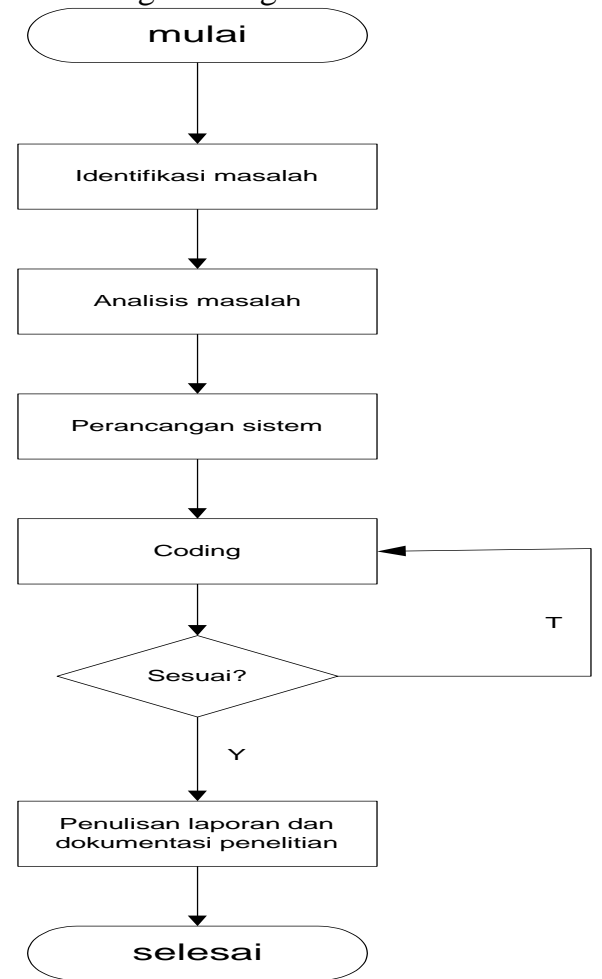

Gambar 4 Flowchart Pelaksanaan Penelitian SI Geofisika

\subsection{Sistem yang Berjalan}

Tabel 1 menjelaskan tentang sistem yang sedang berjalan dikantor stasiun geofisika kelas III ternate, observator melakukan pengisian data dengan mencatat data-data yang ada ke dalam Microsoft Word dan Microsoft Excell, data di berikan kepada seksi sistem informasi atau administrator dimana ditugaskan menerima data dan diperiksa, kemudian membuat laporan diserah kepada kepala Stasiun Geofisika Ternate.

Tabel 1 Sistem yang Berjalan

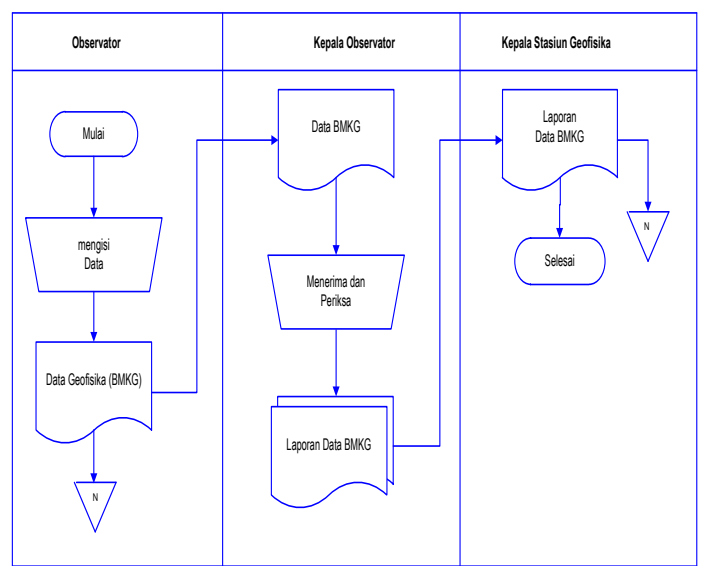

\subsection{Sistem yang di Usulkan}

Tabel 2 menjelaskan alur proses sistem yang akan diusulkan sehubungan dengan pembuatan SI geofisika di kantor Stasiun Geofisika Kelas III Ternate.

1. Observator mempersiapkan data gempa bumi dan tsunami, data penyebaran petir, dan hilal. sebelum di input.

2. Observator membuka website aplikasi sistim informasi geofisika dan login.

3. Observator menginputkan, edit, update dan mengupload pada SI geofisika.

4. Kepala observator menerima dan memeriksa datadata yang telah di input seperti data gempabuumi dan tsunami, data penyebaran petir, dan data hilal.

5. Kepala stasiun geofisika (Kasgeof) melihat datadata geofisika di SI.

6. Masyarakat bisa melihat data gempa bumi dan tsunami, data penyebaran petir, dan hilal.

Tabel 2 Sistem yang Diusulkan 


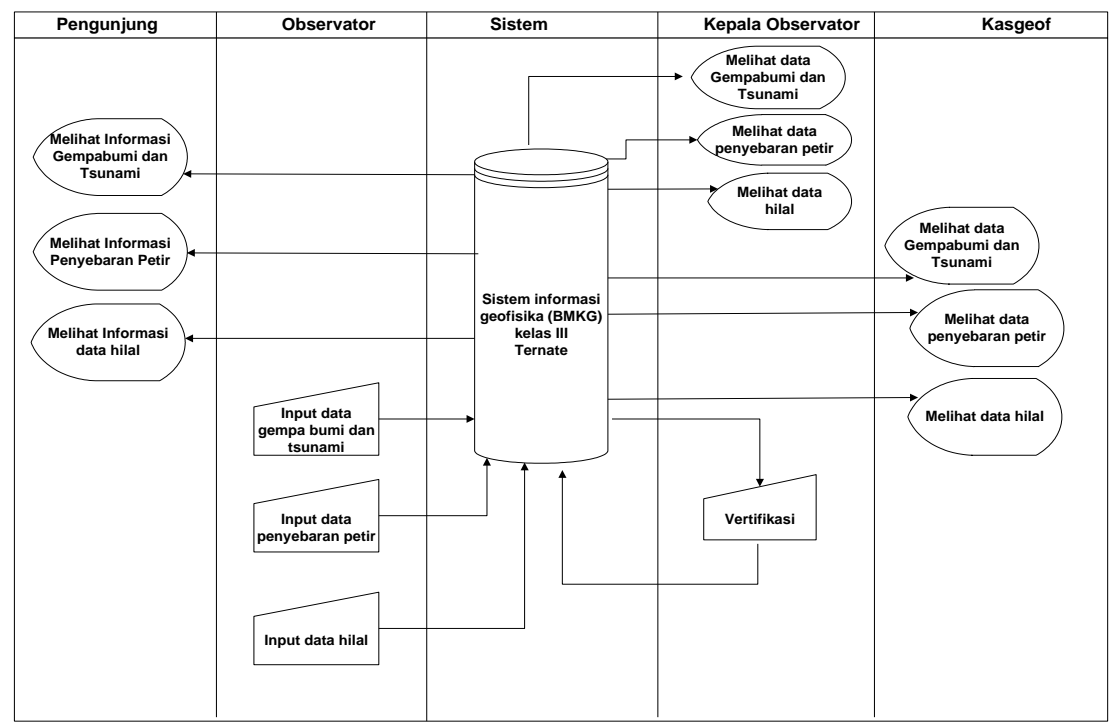

\subsection{Diagram Konteks}

Diagram konteks adalah bagian dari data flow diagram yang berfungsi memetakan model lingkungan, yang dipresentasikan dengan lingkaran tunggal yang mewakili keseluruhan sistem. Untuk lebih jelasnya lihat aliran data dari diagram konteks pada gambar 5 .

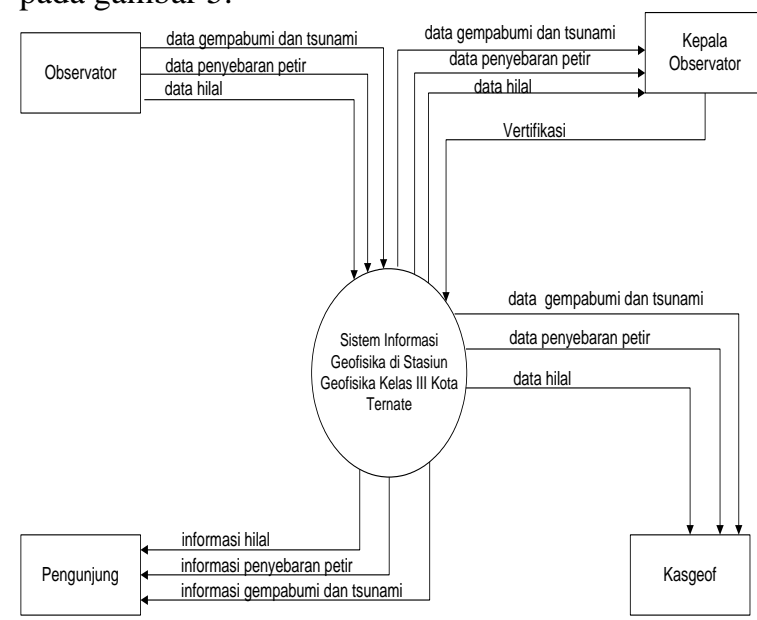

Gambar 5 Diagram konteks SI Geofisika

Berikut penjelasan dari diagram konteks di atas:

1. Observator, seorang administrator yang melakukan login ke dalam sistem serta melakukan input data geofisika berupa data gempabumi dan tsunami, data penyebaran petir dan data hilal.

2. Kepala observator memeriksa data-data geofisika yang telah di input.

3. Kasgeof login dan melihat data geofisika didalam sistem.

4. Pengunjung, melihat sistem informasi geofisika berupa data gempabumi dan tsunami, data penyebaran petir dan data tanda waktu di statiun geofisika kelas III Ternate.

\subsection{ERD (Entity Relationship Diagram)}

Perancangan ERD yaitu untuk Sistem Informasi

Geofisika di Statiun Geofisika Kelas III Ternate ini dapat di lihat pada gambar 6.

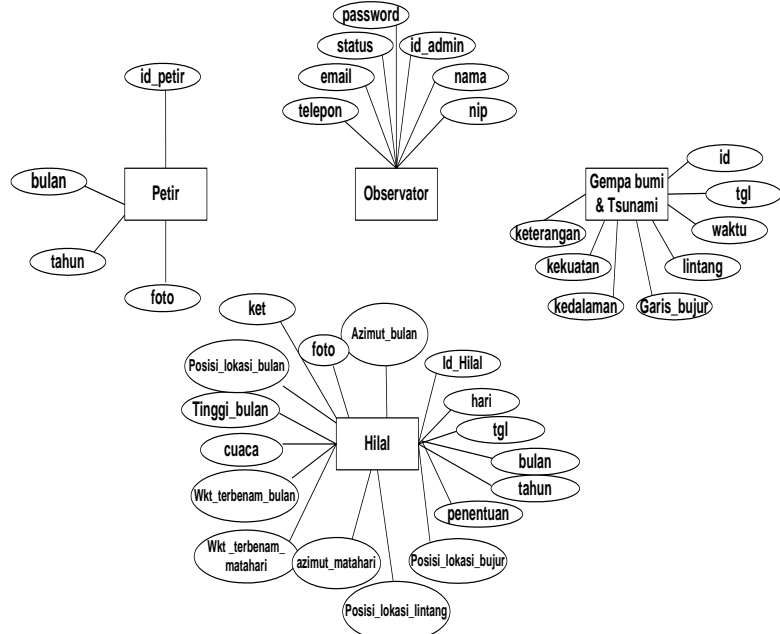

Gambar 6 ERD Sistem Informasi Geofisika 3.7 Perancangan Tampilan Program

Rancangan antar muka atau Interface biasa digunakan untuk membuat tampilan aplikasi dengan tujuan memberikan gambaran kepada pengguna tentang aplikasi yang nantinya akan digunakan.

1. Tampilan Utama Sistem Informasi Geofisika

Tampilan utama atau halaman home akan muncul ketika pertama kali saat pengunjung melakukan browsing Sistem Informasi Geofisika di Stasiun Geofisika Kelas III Ternate Berbasis Web. Rancangan tampilannya dapat dilihat pada gambar 7 .

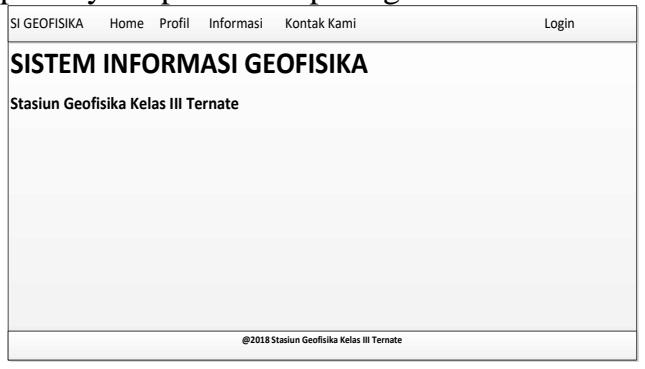

Gambar 7 Tampilan Utama Sistem Informasi Geofisika

2. Tampilan Login 
Tampilan login merupakan rancangan untuk user masuk ke dalam sistem informasi geofisika. Rancangan tampilannya dapat dilihat pada gambar 8 .

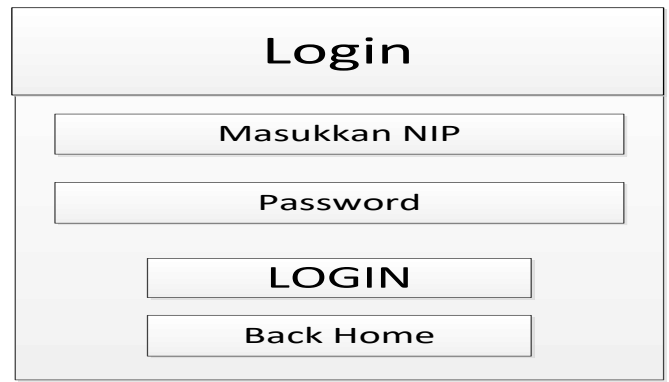

Gambar 8 Tampilan Login Administrator

3. Tampilan Input Data Gempabumi dan Tsunami Halaman data gempabumi dan tsunami merupakan halaman untuk memanipulasi data yang ada pada tabel gempa bumi dan tsunami. Rancangan tampilannya dapat dilihat pada gambar 9 .

\begin{tabular}{|c|c|c|c|c|c|c|c|c|c|}
\hline \multicolumn{10}{|c|}{ Selamat datang Rusdin womboo anda sebagai administrator } \\
\hline \multicolumn{2}{|c|}{ SI GEOFISIKA } & Home $\operatorname{lnf}$ & rmasi & & & & & un $\log 04$ & \\
\hline \multicolumn{7}{|c|}{ Data Gempa Bumi } & \multicolumn{3}{|c|}{ +Tambah Data } \\
\hline No & Tanggal & Waktu & Lintang & Bujur & Kedalaman & Magnitude & Keterangan & Aksi & \\
\hline 1 & 2018-11-10 & 10:33:00 & 3,23 & 126,75 & 10 & 4,9 & $87 \mathrm{Km}$ Selatan sulut & Hapus & Edit \\
\hline
\end{tabular}

Gambar 9 Tampilan Input Data Gempa Bumi dan Tsunami

\section{HASIL DAN PEMBAHASAN}

\subsection{Implementasi Sistem}

Pada implementasi ini ada beberapa software yang digunakan untuk menghasilkan tampilan website sistem informasi geofisika yang diantaranya microsoft windows 7 untuk operasi sistem, notepad ++ untuk menampilkan teks dan berkas kode sumber berbagai bahasa pemograman yang berjalan diatas sistem operasi microsoft windows, xampp sebagai server yang berdiri sendiri (localhost), yang tediri dari beberapa program antara lain apache HTTP server dan MySQL database.

\subsection{Tampilan Aplikasi Sistem informasi Geofisika di} Stasiun Geofisika Kelas III Ternate

Flowchart tampilan utama sistem informasi geofisika, dimana alur diagram ini menunjukan langkah-langkah dari tampilan utama sistem informasi geofisika. Untuk lebih jelasnya dapat dilihat pada gambar 10 flowchart tampilan home.

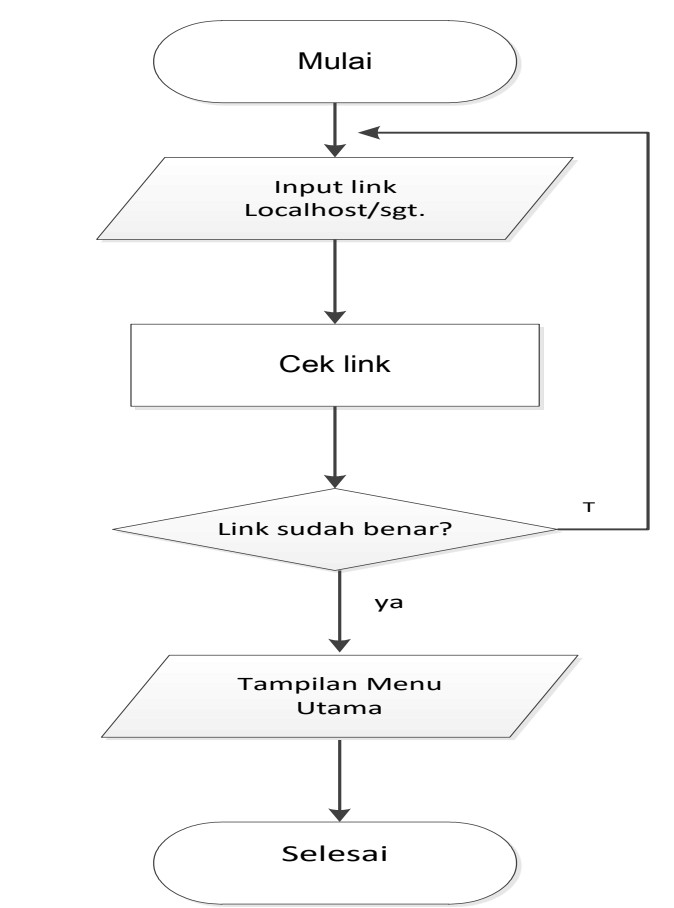

Gambar 10 Flowchart Tampilan Sistem Informasi Geofisika

Pada tampilan home sistem informasi geofisika di stasiun geofisika kelas III ternate ini masyarakat dapat melihat tampilan home. Berikut ini gambar 11 tampilan utama website.

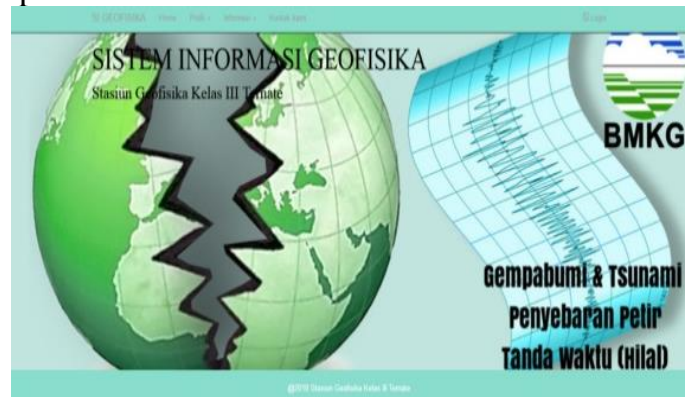

Gambar 11 Tampilan utama website

4.4 Tampilan Input Data Gempabumi dan Tsunami Pada flowchart ini admin dapat menginput data gempabumi dan tsunami, seperti terlihat pada gambar 12 . 


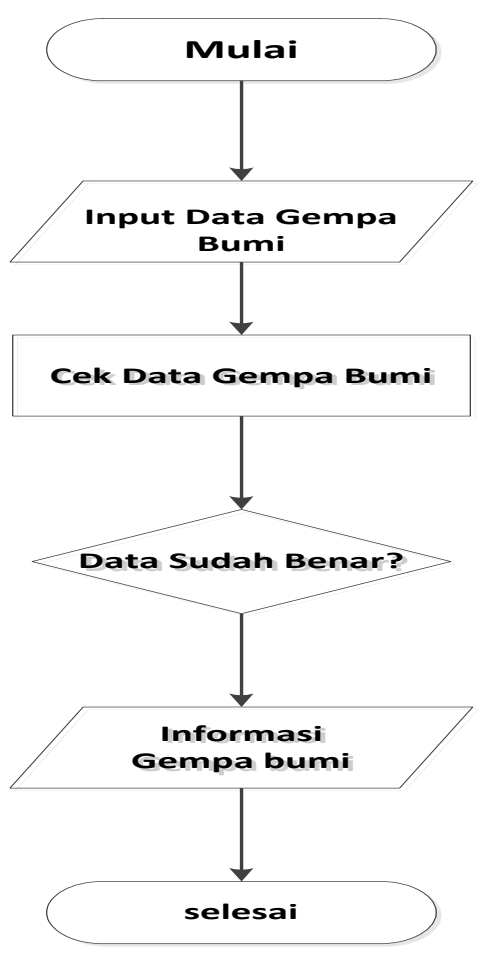

Gambar 12 Flowchart input data gempa bumi dan tsunami

Pada tampilan ini admin dapat menginput data, mengedit dan menghapus data gempabumi dan tsunami yang ada didalamnya. Seperti yang terlihat pada gambar 13 .

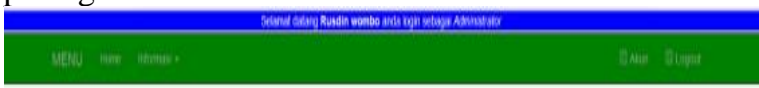

\section{Data Gempa Bumi}
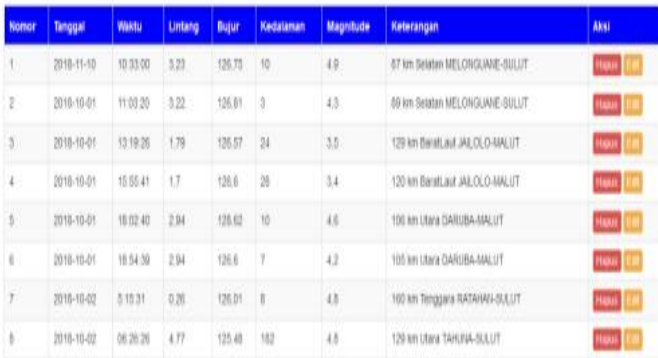

Gambar 13 Tampilan Halaman Input Data Gempa bumi dan Tsunami

\subsection{Pengujian Sistem}

Seperti terlihat pada gambar 14 adalah tampilan halaman login dimana admin memasukkan username dan password pada field yang tersedia untuk masuk ke sistem.

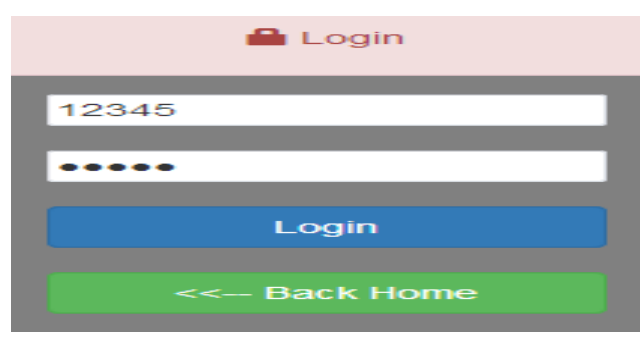

Gambar 14 Halaman Login

Tabel 1 Pengujian vertifikasi data login salah

\begin{tabular}{|l|l|l|l|}
\hline \multicolumn{4}{|c|}{ Hasil Uji (Data Salah) } \\
\hline $\begin{array}{l}\text { Data } \\
\text { Masukkan }\end{array}$ & $\begin{array}{l}\text { Yang } \\
\text { Diharapkan }\end{array}$ & Pengamatan & Kesimpulan \\
\hline $\begin{array}{l}\text { User: } \\
12345\end{array}$ & $\begin{array}{l}\text { Username } \\
\text { password } \\
\text { salah atau } \\
\text { tidak } \\
\text { Pass: } \\
\text { advfg }\end{array}$ & $\begin{array}{l}\text { Username dan } \\
\text { password } \\
\text { salah mak } \\
\text { muncul } \\
\text { pemberitahuan } \\
\text { login gagal..!! } \\
\text { password atau } \\
\text { username } \\
\text { salah }\end{array}$ & \\
\hline
\end{tabular}

Pada tabel 1 menampilkan pengujian veritfikasi data login salah, gambar 15 adalah tampilan pesan peringatan bawah login gagal. Login dinyatakan gagal apabila admin atau petugas memasukan username dan password yang salah atau tidak sesuai. Sehingga admin dapat melakukan login kembali.

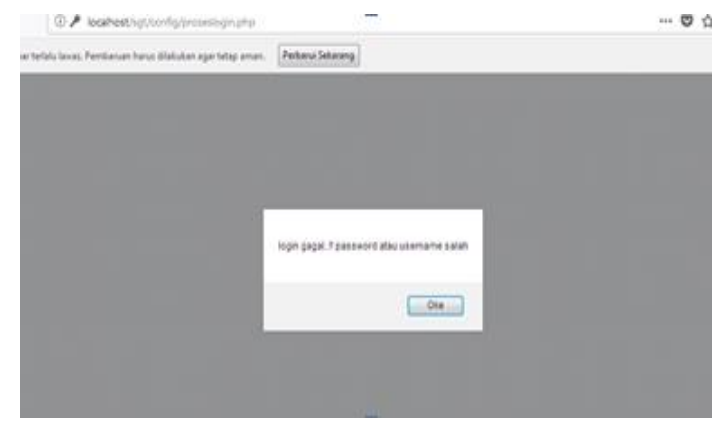

Gambar 15 Halaman Login Gagal

\subsection{Analisa Pengujian}

Pada analisa penguian ini bertujuan untuk mengetahui sistem yang diuji sudah sesuai dengan implementasi atau belum. Implementasi yang dimaksud adalah dalam pembuatan aplikasi yang berbasis web pertama yang harus dipelajari agar aplikasi yang dibuat dapat berjalan.

Dari penjabaran pada perancangan sistem informasi geofisika di stasiun geofisika kelas III ternate, penulis dapat membuat hasil dan pembahasan yang dimana pada tahap implementasi sistem merupakan tahap penerapan yang telah didesain atau dirancang, sehingga sistem yang telah dibuat dapat dioperasikan dan digunakan secara optimal dan sesuai dengan kebutuhan. Pada implementasi untuk membuat program, pada langkah pertama penulis membuat flowchart disetiap tampilan aplikasi untuk mengetahui 
langkah-langkah input sampai ke outputnya. Setelah membuat flowchart untuk langkah selanjutnya penulis menampilkan script pada laporan untuk mengetahui setiap tampilan aplikasi yang sudah jadi.

Pengetahuan tentang aplikasi yang dipakai untuk membuat suatu sistem informasi. Pembuatan aplikasi sistem informasi berbasis web ini menggunakan notepad ++ dan databasenya menggunakan phpMyAdmin. Pengujian yang dilakukan dengan menggunakan metode Black Box. Hasil yang akan diuji data benar atau data salah yang pertama setelah masuk ketampilan awal aplikasi terdapat satu pilihan login admin. Apabila pada pengisian username dan password dan ditolak oleh sistem, berarti ada kolom tidak terisi atau username dan password salah, data diuji salah pada sistem yang berjalan dengan baik dan benar.

Adapun kelebihan dari sistem ini adalah bisa diakses kapan saja dan diaman saja asalkan mempunyai akses internet. Sedangkan kekurangan dari sistem informasi ini adalah masih sederhana.

\section{PENUTUP}

\subsection{Kesimpulan}

Berdasarakan hasil implementasi yang telah dilakukan dalam pembuatan sistem informasi geofisika di stasiun geofisika kelas III ternate dapat ditarik beberapa kesimpulan dan saran dari penelitian ini yaitu:

1. Aplikasi sistem informasi geofisika di stasiun geofisika kelas III ternate yang dibuat menggunakan phpMyAdmin, xampp, php dan html, dan microsoft visio 2010 dalam proses implementasi tersebut berjalan dengan baik, itu dibuktikan dengan adanya sistem yang berjalan dan juga telah diuji.

2. Dalam pengujian yang menggunakan black box telah menunjukan bahwa sistem telah berjalan dengan baik. Yaitu pengujian tampilan login karena setelah pengisian username dan password yang benar maka admin akan masuk ke dalam menu utama aplikasi.

3. Dalam menganalisa dan merancang sistem informasi geofisika di stasiun geofisika kelas III ternate ini adapun tahap wawancara untuk mengetahui permasalahan yang ada di stasiun geofisika, sekaligus mengumpulkan data dan mengadakan tanya jawab secara langsung kepada kepala stasiun mengenai data-data yang dibutuhkan untuk membuat aplikasi berbasis web ini. Untuk tahap perancangan yang penulis terapkan dalam pembuatan sistem informasi berbasis web ini adalah microsoft visio 2010, dimana pada aplikasi ini dapat membuat flowchart diagram yang penulis inginkan.

4. Aplikasi sistem informasi geofisika ini dapat membantu masyarakat mengakses informasi geofisika seperti data-data gempabumi dan tsunami, data penyebaran petir dan data tanda waktu( hilal)

\subsection{Saran}

Agar dapat menggunakan aplikasi dengan baik, maka diberikan saran-saran sesuai penulis dalam menyelesaikan tugas akhir ini:

1. Diharapkan perlu adanya sistem informasi berbasis web ini untuk penelitan sesudahnya. Seperti dikembangkan ke dalam sistem yang berbasis android untuk lebih memudahkan pengguna menggunkan ke smartphone.

2. Data-data yang sudah lama sebaiknya dibackup guna untuk menghindari kehilangan data bila terjadi kerusakan pada sistem atau perangkat keras

\section{DAFTAR PUSTAKA}

[1] Arief Mustofa Nur, 2010, Gempa Bumi,Tsunami dan Mitigasinya, Balai Informasi dan Konservasi Kebumian Karangsambung - LIPI, Kebumen, Volume 7 No. 1 Januari 2010.

[2] BMKG, 2016 http:/ /www. bmkg.go.id/ profil/ ? $\mathrm{p}=$ sejarah (diakses tanggal, 25 Desember 2017)

[3] Indrajani, 2007, Pemrograman berbasis Objekdengan Bahasa Java, Jakarta, PT.AlexM ed ia Komputindo.

[4] Jogiyanto, H.M., 2005,Analisa dan Desain Sistem Informasi: Pendekatan Terstruktur Teori dan Praktik Aplikasi Bisnis, ANDI, Yogyakarta.

[5] Roni Andarsyah, 2017, Rancang Bangun Sistem Informasi Meteorologi Klimatologi Dan Geofisika Di Stasiun Bmkg Kelas 1 Bandung Berbasis Web (Studi Kasus Bmkg Bandung), Politeknik Pos Indonesia, Junal Teknik Informatika Vol. 9 No. 1, Januari 2017

[6] A. S. Soroto, A. Fuad, and S. Lutfi, "Penerapan Metode Case Based Reasoning (CBR) Untuk Sistem Penentuan Status Gunung Gamalama," JIKO, vol. 02, no. 2, pp. 70-75, 2018.

[7] Tommy Ilyas, 2006, Mitigasi Gempa dan Tsunami di Daerah Perkotaan, Guru Besar Geotechnic, Fakultas Teknik, Universitas Indonesia, Seminar Bidang Kerekayasaan, Fatek-Unrat 2006. 